\title{
THE CHINESE EXPERIENCE IN PROMOTING TEACHER PROFESSIONAL DEVELOPMENT IN DISADVANTAGED AREAS
}

\author{
Gong Chen \\ Faculty of Education, Beijing Normal University (China)
}

\begin{abstract}
Teacher is the quality safeguard of education and the practitioner of education reform. Due to the difference between urban and rural, it couldn't be ignored that teachers are exposed to the dilemma between teaching and training, the weak of teaching ability and the increasingly job burnout in disadvantaged areas in China. It's no doubt that teacher in-service training is the key to promote teacher professional development. However, there are also many problems as well, such as the rarely opportunities to training, the lack of practical content in training, the lower quality of training. In order to give full play to outstanding teachers acting as teacher educators, "Master Teacher Studio" is established. It could promote accumulating teachers' practical knowledge, improving abilities of reflection and teaching research, and alleviating teacher's job burnout, by means of expert lecture, educational research, different teaching for the same course, reading \& sharing, reflection \& communication. As a kind of teacher learning community, it is important to cultivate outstanding teachers and improve the quality of teachers in disadvantaged areas.
\end{abstract}

Keywords: Master Teacher Studio, teacher training, teacher professional development, teacher education in disadvantaged area.

\section{Introduction}

As an important cornerstone of education, the quality of teachers affects and even determines the quality of education. As Chinese socialist construction enters a new era, the contradiction between the people's demand for high quality education and the unbalanced and inadequate development of education is increasingly prominent. Therefore, improving the overall quality of teachers in rural to provide students with satisfactory education has become a great pursuit of Chinese educational development.

The existing approaches to promote teacher professional development in disadvantaged areas mainly focus on teacher research, teacher reflection, teacher training, expert guidance and teacher learning. Compared with developed areas where are rich in advanced educational resources, rural teachers rarely go out of town to participate in long-time training due to the lack of opportunities and workload. It's also difficult to invite experts to the countryside with the long distance and high cost (Chen \& Guo,2018). There is study revealing that teachers in disadvantaged regions more prefer to discuss their teaching problems with peers and learn from experienced teachers. This harmony teacher cooperation makes up for the shortage of high-quality teacher training resources in disadvantaged areas. Meanwhile, this informal conversation during the rest becomes an opportunity for the development of teachers (Wohlfahrt, 2018). However, it's difficult to give their valid direction to solve the problems because of the low quality in peers. Therefore, in order to give full play to the effectiveness of teachers' cooperative learning, it is necessary to establish a high-quality teacher education resource supply mechanism (Thornton, 2006).

In March, 2018, the Ministry of Education issued "Revitalization of teacher education (2018-2022)", which calls for the establishment of "Master Teacher Studio" in primary and secondary schools, also pay more attention to the superfine teacher and expert teacher who have heavily impact on others. There is also research suggesting that it's necessary to build a teacher group full of leadership that could improve the quality of the whole teacher in disadvantaged areas. Therefore, the Master Teacher Studio must be established to give full play to the leader role of the superfine teachers, leading teacher, expert teacher and other outstanding teachers (Zhu, 2011\&2019).

The Master teacher Studio is a teacher learning community composed of teaching, teaching research and training, which is presided over by an outstanding teacher and made up of a certain number of teachers. As a form of teacher training, the Master Teacher Studio has been adopted by Guangdong Province (Hu \& Gu, 2011), Gansu Province (He, 2014) and other regions in China. It has the most personalized path of teacher professional development, and it is favored by novice and mature teachers. No doubt, it is worth to looking forward to its prospect (Zhu \& Wang, 2012). 


\section{Master Teacher Studio}

In 2002, there are 18 Master Teacher Studios established by the Education Bureau of Baoshan District, Shanghai, that opened the episode of the development of Master Teacher Studio in China. The Master Teacher Studio is a teacher professional community organized and coordinated by the educational administration department or school leaders, named according to the name of the host or professional characteristics (Zhu \& Wang, 2012). It is composed of an outstanding teacher, some of mature teachers and novice teachers (Zhu \& Yan, 2019). The differences in the number and composition of members lead to different organizational structures of Master Teacher Studio.

It has strict access system and conditions. All the members must pass through strict application, assessment and selection procedures (Wu, 2012). As the host, outstanding teacher is responsible for maintaining the stable implement of the studio, planning the development goal of the studio, designing and carrying out learning activities, evaluating the result of the studio and giving play to the radiation effect of the studio ( $\mathrm{Hu}, 2012)$. Studio host is usually selected and appointed by the provincial, local or district educational administration according to the candidates' titles and professional development degree. In addition, the selection of member teachers is in full charge of the studio host, mainly in the form of school recommendation, host assessment and free declaration.

The Master Teacher Studio aims at helping more teachers to achieve their development goals (Xu \& Miu, 2012). So there are so many activities, including expert lecture, educational research, different teaching for the same course, reading \& sharing, reflection \& communication and others.

\section{The advantage of Master Teacher Studio in teacher training}

Education plays a fundamental, guiding and sustainable role in poverty alleviation. Teachers are the foundation of the education and the key to improve the quality of education in disadvantaged areas (Zhang \& Fu, 2016). Under the background of the teachers' demand of lifelong learning, teacher training is an effective way to promote teacher professional development (Zhu \& Song, 2013). However, compared to urban teachers, there are so many issues in rural teacher training that couldn't be ignored any more. First, the opportunities to the high-quality teacher training are scarce. Overall, most rural teachers go out for training mainly at the district or county, because the provincial-level and national-level Training is untouchable for them. Even worse, a part of teachers has no chance to training any level in their career in western countryside of China (Chen \& Wang, 2013). Second, the training quality is unsatisfied without effectiveness. The training is often complained because the trainers, served by scholars, are full of theory but lack of practical knowledge, even they couldn't understand what the trainees experienced in practice especially they from where are completely different teaching situation (Zhang \& Wei, 2016). In addition, due to the lack of teaching equipment in disadvantaged area, the knowledge and skills learned by teachers in the training are less transferred in practice, which makes the effect of training on improving the quality of rural education not obvious (Chen \& Hu, 2011). Third, the inevitable contradiction between teaching work and training is prominent. There aren't always sufficient numbers of teachers to replace to accomplish daily teaching in rural and disadvantaged areas when teachers go out to take part in training that is remote and long-term (Rong, 2014).

Compared with the traditional teacher training, the Master Teacher Studio is of great significance to teacher professional development in disadvantaged areas. First, it brings high-quality training resources to disadvantaged areas. The studio host, who is possess with profound knowledge, abundant experience and superior ability, makes it possible for others to get access to high-quality training resources. Second, it effectively promotes professional development of each one in community. In view of ecologically orientated teacher development, it tends to focus on developing by constructing relationship between members (Liu \& Luo, 2012). Third, the studio host and members are from the same region so that they have the same cultural background, as a result, it is possible for trainees to learn together without the cultural barrier that could be benefit to cross-school communication. The last, it could be more efficient for teacher training. There are weekly learning activities organized by studio host that makes all of problems could be communicated instantly at any time.

\section{The function of Master Teacher Studio}

The pursuit of Master Teacher Studio is that by attracting a group of teachers with common education ideal to build an excellent team to advocate to educational researches, explore educational principles, spread advanced teaching thoughts and methods (Xu \& Miu, 2012), transfer teachers' practical knowledge (Zhu \& Wang, 2012), and improve the quality and quantity of the whole teachers by means of taking advantage of outstanding teachers as learning-leaders (Quan, 2009). 


\subsection{Master Teacher Studio integrates and provides high-quality training resources}

In disadvantaged areas, although it is difficult for general teachers to have direct access to experts and scholars by themselves, Studio host is the important and even the only way for them to get high-quality learning resources. On the one hand, studio host is the supplier as the result of its expertise that the host has own unique teaching experience, structure of knowledge, teaching skills and teacher beliefs, so that it tends to adopt different strategies while facing the same teaching problems (Quan, 2009). On the other hand, it not only provides with high quality training resources, but also knows how to integrate resources to meet the needs of members. The studio host, selected by local bureau of education, is full of social capital because it generally holds administrative positions in school or have intergenerational relations with other outstanding teachers. Therefore, studio host could introduce university or teaching experts into the studio relying on its social capital, so as to help members to broaden their horizons and enrich their learning (Zeng \& Zhang, 2016).

\subsection{Master Teacher Studio promotes teacher professional development}

The Master Teacher Studio has become the cradle of eminent teachers by promoting teachers to accumulate professional knowledge and improve teaching skills (Han, 2015). Teacher professional development is equal to a process that they obtain practical knowledge (Wang, $\mathrm{Xu}, 2008$ ). Practical knowledge is a kind of thoughts of education that they believe sincerely and use in practice (Chen, 2009). The core of Master Teacher Studio is to interchange and innovate their practical knowledge among members (Zhu, 2013). There are plenty of activities organized in order that studio host could stimulate members to transfer fragmentary implicit knowledge into systematic explicit knowledge so that pass it conveniently through communication (Shan \& Liu, 2015). Moreover, the members' research and reflective ability also are cultivated. In general, educational research is always regard as the privilege of scholars. But now, it was broken through they carry out research for purpose of solving actual problems (Han, 2015). The last, the Master Teacher Studio aims at breaking the "plateau period" in teacher career and explore new development chance (Cui, 2015), by means of making closely contact between outstanding teachers and members. So it could help to activate teachers' agency (Zhang, 2017), recall teachers' identity, alleviate their job burnout (Dong, 2019).

\subsection{Master Teacher Studio improves the quality of education in disadvantaged areas}

There is study proposing that it is possible to establish Mater Teacher Studio to promote the development of education in rural and nearby areas (Rong, 2014). Dongying Shengli Central for Education has made progress on improving the quality of teachers by establishing Master Teacher Studio in remote areas of Shandong Province (Ren \& Li, 2011). Meanwhile, "Wang Aihua Master Teacher Studio" has also explored an efficient approach to rural teacher training. Wang Aihua, the studio host, takes the elaborated courses and provides valid instruction to countryside. There also some rural teachers are admitted as members in her studio (Wang \& Qi, 2019). Therefore, the Master Teacher Studio isn't only to promote teacher professional development. More importantly, it must aim at diffusing the achievements to the wholly district, in order that could promoting balanced education development (Xiao, 2014). In another word, the outstanding teachers who are remarkable and influential should be taken account into promoting teacher professional development as the learning-leader, and their teaching practical knowledge and education wisdom should be also explicated and learned in disadvantaged areas.

\section{Conclusion}

The Master Teacher Studio is an important practical product of the development of education in modern. As a region-specific teacher training system, it has become an efficient form to promote the development of teachers in disadvantaged areas. As the collection of high-quality training resources, it could improve the quality of teacher by sharing the resources to the whole region, and even gives a hand to the other places. It has gradually formed a model of open-resource teacher training.

\section{References}

Chen, C., \& Hu, Y. (2011). An empirical analysis of teacher quality and its influence factors in western rural China among primary and secondary schools. Teacher Education Research, 23(03),61-65.

Chen, E. (2018). Promoting targeted poverty through teacher training. Journal of the Chinese Society of Education, $04,42-46$.

Chen, X. (2009). On the constituting components of teachers' practical knowledge. Educational Research,30(10):66-73. 
Chen, X., \& Wang, Z. (2013). A Study on the Training of Teachers for the Compulsory Education. Open Education Research,19(04),11-19.

Cui G. (2015). The orientation difference between Master Teacher Studio and the teaching and research group. The Inservice Education and Training of School Teachers, 07,68-70.

Dong, S. (2019). Study on the operation mechanism of Master Teacher Studios in primary and secondary schools from the perspective of teacher professional development. Journal of Teaching and Management, $12,48-50$.

Han, S. (2015). Study on the operation masters studio on the orientation of teachers' professional development: a case study on masters studio of middle and primary school of Jinlin Province. (Doctoral dissertation Northeast Normal University, Changchun, China). Retrieved from http://xueshu.baidu.com/usercenter/paper/show?paperid=0ca5afab7f845b422331ba34640ec7ec\&si te $=$ xueshu_se.

He, Y. (2014). Reforming Teacher Training Modes to Promote Teachers' Professional Development. Educational Research,35(01),150-153.

Hu, J., \& Gu, L. (2011) Construction of "four mains and four rings" as teacher training mode. Journal of Chinese Society of Education,12,73-75.

Liu, Y., \& Luo, S. (2012). On the ecologically oriented teacher professional development. Journal of Education Development,08,73-75.

Quan, L. (2009). Teacher professional development in Master Teacher Studio: a perspective of professional community. Contemporary Education Sciences, 13,31-34.

Ren, G., \& Li, W. (2011). Exploration of the operation mechanism of Master Teacher Studio. Contemporary Education Sciences, 14,30-32.

Rong, Z. (2014). A research of the problems in the rural teacher training on the background of sate training policy: policy suggestions based on a survey in Zhejiang, Hebei, and Sichuan provinces. Research in Educational Development,33(12),7-10.

Shan, H., \& Liu, L. (2015). Master Teacher Studio from the perspective of reflective practice: thoughts, principles and process. Research in Educational Development,35(12),46-51+64.

Thornton, H. (2006). Teachers talking: the role of collaboration in secondary schools in Bangladesh. Compare: A Journal of Comparative and International Education,36(2),181-196.

Wang, A., \& Qi, J. (2019) Practice and effect of rural teachers training by Master Teacher Studio. Chinese Journal of Chemical Education, 40(13),97.

Wang, J., \& Xu, L. (2008). The implication and approach of teacher professional development: teacher practical knowledge as the core. Journal of Central China Normal University (Humanities and Social Sciences), 03, 125-129.

Wohlfahrt, M.U. (2018). Primary teacher education in rural Cameroon: Can informal learning compensate for the deficiencies in formal training?. Africa Education Review,1-20.

Xiao, L. (2014). Exploring the effectiveness of the construction of Master Teacher Studio in the region: a case study in Nanjing. Journal of the Chinese Society of Education,10,75-78.

Zeng, Y., \& Zhang, J. (2016). The practice and dilemmas when master teachers acting as learning-leaders: A Case Study of Master Teacher Studios in Shanghai. Teacher Education Research,28(04),92-98.

Zhang, C., \& Fu, W. (2016). Research on education support policy for poor areas in developed countries and its enlightenment to targeted poverty alleviation in China. International and Comparative Educatioin,38(06),77-83.

Zhang, L. (2017). From outshine others to diversity in unity: a case study of teachers' studios in secondly vocational schools. Teacher Education Research,29(03),69-74.

Zhang, M., \& Wei, C. (2016). Research on the existing problems of rural teacher training and its countermeasures. Teacher Education Research,28(05),74-79.

Zhu, G. (2013). To improve the Effective of Master Teacher Studio: a case study in Changzhou, Jiangsu province. Journal of the Chinese Society of Education, 07,81-84.

Zhu, N., \& Y, Y. (2019). Analysis of The Famous Teacher's Identity: Return Expansion and Transcendence. Education Science,35(02),22-27.

Zhu, W., \&Wang, Y. (2012). Four approaches to teacher professional development under ecologically oriented. Theory and Practice of Education,32(02),24-27.

Zhu, X. (2011). Discussion of reconstruction of rural teacher training configuration in China. Teacher Education Research,23(06),1-8.

Zhu, X. (2019). Revaluation of the National Training Plan in the process of constructing a new system of teacher education in administrative districts and counties. Journal of Yunnan Normal University (Humanities and Social Sciences Edition),51(03),93-99.

Zhu, X., \& Song, H. (2013). On the key elements of teacher training. Teacher Education Research, 25(03), $1-8$. 